\title{
nature
}

\section{Iraqis must not use gas again}

The welcome ending of the war between Iran and Iraq should not blind governments elsewhere to Iraq's use of poison gas - and to the need that it should not be allowed to happen again.

THE prospect of at least a temporary halt in the eight-year war between Iran and Iraq is welcome not only in the Middle East but also far from the Gulf. The great damage the combatants have inflicted on each other for no great gain on either side is bad enough to contemplate. The ever-present danger, during the past decade, that the conflict would be enlarged has been hairraising; at different times, one adversary or the other has seemed deliberately bent on doing just that, by hostage-taking and attacks on merchant shipping. Although the conflict has mercifully been contained, non-combatants of all kinds have been sullied by it. Too many states whose wider interests were threatened by the war have emerged as partisan arms suppliers eager to tilt the balance one way or the other, while the discovery that the Reagan White House, with or without authority, was seeking to trade arms for hostages has unhappily renewed the corrosive atmosphere engendered by earlier scandals. But relief that these tensions may now be abated should not blind us to one particularly sinister aspect of the war between Iraq and Iran - the unconvincingly disputed use by Iraq of poison gas against Iranian troops and, possibly, civilian targets during the past few years.

That there is something peculiarly horrible about death by poisoning on a battlefield is not what matters most. In respect of those who die or are injured in battle, it probably makes no difference in the long run whether the damage is done by bullets or by gas. What does matter is that Iraq is a signatory of the Geneva Convention and its protocols which, for practical purposes, formally require that signatories should not use chemical gases as weapons except by way of retaliation in kind.

Iraq's use of gas during the Gulf war is therefore a sign that even states not ranked as major powers can shrug off solemn international obligations when it suits them. That in itself is a chilling precedent that should not be overlooked in the general euphoria that the war in temporarily ended. One Iraqi defence against the pressure that should now be exerted by the major powers against Iraq will no doubt be that nothing was done to penalize Israel for its equally lawless attack on the Tamuz research reactor in 1981 (see Nature) 291, 523; 1981. The reply will have to be that, in international relations, one injustice does not sanction others.

The precedent set by Iraq is a poser for the major powers because it will invite imitation by other states precisely when they are trying (at Geneva) to work out among themselves means of turning the Geneva convention as it applies to them into a verifiable ban on the manufacture of chemical weapons. The plain truth is that the technology of the manufacture of poison gas, and the munitions required to carry it against targets, is among the easiest to acquire. States that would not dream of becoming independent of friendly suppliers in, say, battle tanks, can realistically seek to tuck away a clandestine chemical plant making derivatives of phosgene or even nerve gases. On the face of things, Iraq has shown would-be imitators how to do just that. And how to get away with it.

The United Nations, showered with unaccustomed approbation for having organized the truce, has a crucial part to play in the months ahead. Its own unsolicited documentation of Iraq's transgressions appeared as the truce negotiations reached their most delicate stage, and were no doubt underplayed in the hope of securing Iraq's reluctant signature. Quite apart from the need for diplomatic pressure on Iraq, there is now an urgent need of more detailed information about the means by which Iraq manufactured its chemical weapons and the uses it made of them in the war. The second point is especially important. Iran has understandably protested vigorously about the numbers of people killed and injured by Iraq's poison gas, in the process creating the impression that it was an effective weapon of war. But the chances are that the truth is quite different; for all its horrors, poison gas is more a blunderbuss than a rifle. The threat that it will be used in a war such as that in the Gulf is most likely to encumber combatants with the requisite logistical preparations. Thus an objective evaluation of the uses made of gas during the past eight years may help to persuade other states that this bizarre game is not worth the candle, even in military terms.

But pure reason will not suffice for dealing with Iraq. For that purpose, it is essential that Iraq's international associates, and especially its conventional arms suppliers, should resolve that the use of gas in violation of the Geneva Convention should be penalized effectively. The danger, even when the truce comes into effect, is that arms suppliers will continue calculating how their trade will help shift the tactical balance between Iran and Iraq even though the war is technically over, compromising their long-term interests in the process. Governments elsewhere should recognize that seeming to condone Iraq's use of poison gas by continuing to supply arms of other kinds without demanding a compensatory undertaking to dismantle existing facilities for producing poison gases will be as short-sighted as to seek to trade arms for hostages.

\section{Nuclear togetherness}

\section{Distinctions in the United States between civil and military nuclear power may soon be blurred.}

Although the past few years have not been auspicious for reactor-builders in the United States, let alone for those who would develop new designs, the US Department of Energy seems about to embark on such a course (see page 558). The department's plans are born of necessity: new facilities to produce tritium and weapons-grade plutonium are required to replace ageing reactors whose life is being stretched to meet production needs. Two reports from the National Research Council (the research arm of the US academies) show clearly that it is no longer safe to limp along in this way. Many of the serious safety issues the council has identified are unrelated to the age of the military reactors, but it is also inevitable that the risks will be magnified as the military reactors grow old. Current arms control negotiations notwithstanding, something must be done.

While the need for new reactors is military, it is inevitable that the Department of Energy, which also has civil responsibilities, should think of killing two birds with the same stone - winning civil as well as military benefits from the very considerable sum it will have to spend on new military reactors. After all, the 